Pamela J. Shaw Christoper J. Eggett

\section{Molecular factors underlying selective vulnerability of motor neurons to neurodegeneration in amyotrophic lateral sclerosis}

larly vulnerable to calcium toxicity following glutamate receptor activation. Motor neurons also have a high perisomatic expression of the glutamate transporter protein EAAT2 and a very high expression of the cytosolic free radical scavenging enzyme $\mathrm{Cu} / \mathrm{Zn}$ superoxide dismutase (SOD1) which may render this cell group vulnerable in the face of genetic or post-translational alterations interfering with the function of these proteins. More detailed characterisation of the molecular features of human motor neurons in the future may allow the strategic development of better neuroprotective therapies for the benefit of patients afflicted by ALS.

Key words Motor neurons . Selective vulnerability . Amyotrophic lateral sclerosis
Department of Neurology, Ward 11, Royal Victoria Infirmary,

Newcastle upon Tyne, NE1 4LP, UK

Tel.: +44-190-2325131 ext 24950

Fax: +44-191-2610881

e-mail: Pamela.Shaw@ncl.ac.uk
GluR2 AMPA receptor subunit may

render human motor neurons particu-

\section{Introduction}

Amyotrophic lateral sclerosis (ALS) is a progressive neurodegenerative disorder involving primarily the motor neurons of the cerebral cortex, brain stem and spinal cord. The selective vulnerability of motor neurons in ALS is a relative feature. Recent clinical and pathological studies have shown that involvement outside the motor system is relatively common in ALS. Thus other long tracts including the ascending dorsal column sensory pathways [36] and the ascending spinocerebellar pathways [83] may show degenerative changes. The substantia nigra shows depletion of neurons in many cases of ALS, especially ALS-dementia [55] and pathological changes may be found in dentate granule cells in the hippocampus. Dementia is found in approximately $2-3 \%$ of ALS patients [33] and detailed neuropsychological testing has shown that subclinical changes, particularly affecting frontal function, are more common than previously recognised $[1,16,66]$. Thus, ALS is now regarded as a multisystem degenerative disease, in which the earliest and most severe degenerative changes tend to affect lower and usually upper motor neurons. Even within motor neuron groups, there is selective vulnerability. Certain groups of motor neurons, including those controlling eye movements and those in Onuf's nucleus in the sacral spinal cord controlling the pelvic floor muscles, tend to be spared in ALS in comparison to other groups of motor neurons. Thus, the comparative neurochemistry of vulnerable and spared 
motor neuron groups may give us some important insights into selective vulnerability.

In this paper, factors which may contribute to the selective vulnerability of motor neurons to the neurodegenerative process occurring in ALS will be considered.

\section{Cell size}

Motor neurons differ from many other groups of cells in that they are large cells with a somatic diameter of approximately $50-60 \mu \mathrm{M}$ and a very long axonal process. In the spinal cord, motor neurons which supply the muscles of the distal lower limb might possess axons of up to one metre in length. As a consequence of these anatomical features one would predict that motor neurons must have high energy demands and a high metabolic rate, necessitating a high level of mitochondrial activity. To link with muscle fibres the motor neuron needs to support a long axonal process with a robust internal skeleton. Thus, these cells have a very high content of neurofilament proteins compared to other groups of neurons. These two features will be considered in more detail below.

\section{Mitochondria and motor neurons}

The mitochondrial respiratory chain is one of the main sites for the intracellular generation of free radicals. Therefore neurons with a high level of mitochondrial activity, such as motor neurons, may well be exposed to higher than average oxidative stress. Such neurons may also be more vulnerable to the development of energy deficit in the face of age-related deterioration in mitochondrial function, occurring due to the accumulation of mutations and oxidative damage to mitochondrial DNA [67]. These changes could lead to vulnerability to secondary excitotoxicity, where in the face of impairment in cellular energy production, normal levels of glutamatergic stimulation can generate toxic effects [6].

Mitochondrial function has not yet been extensively studied in ALS, but there is emerging evidence that mitochondrial impairment may be of importance. Morphological changes in mitochondria have been observed in both hepatocytes and in anterior horn cells in ALS and mitochondrial dysfunction has been noted in lymphocytes from ALS patients [23]. Decreased cytochrome oxidase C activity in the ventral horn of ALS spinal cord has been observed [30]. More recently a microdeletion in subunit 1 of cytochrome oxidase $\mathrm{C}$ in a patient with an ALS phenotype has been reported [19]. Finally, in reports of pathological changes in mutant $\mathrm{Cu} / \mathrm{Zn}$ superoxide dismutase (SOD1) transgenic mice it has been emphasised that vacuolar distortion of mitochondria occurs at an early stage in the cascade of motor neuron injury, prior to the appearance of clinical signs of motor dysfunction [17, 42, 93].
The possibility that mitochondrial dysfunction may be important in the pathways leading to motor neuron injury and cell death needs to be more systematically evaluated.

\section{Cytoskeletal components of motor neurons}

The long axons of motor neurons necessitate a strong internal skeleton and these cells therefore have a very high neurofilament content compared to other groups of neurons. Neurofilament proteins constitute a major component of the cytoskeleton of neurons and have significant roles in the maintenance of cell shape and axonal calibre as well as in axonal transport. There are three neurofilament subunit proteins of differing molecular weights, NF-heavy, NF-medium and NF-light. The smallest protein NF-L makes up the core of the neurofilament, while the two larger proteins are arranged around this core and contribute to the projections or side arms radiating from the filament [58]. Neurofilament subunits are assembled in the cell body of the motor neuron and are transported down the axon at a rate of approximately $1 \mathrm{~mm}$ per day. Progressive phosphorylation of neurofilament epitopes occurs during axonal transport.

For a number of reasons neurofilament proteins are implicated in ALS as potential cellular targets for injury. The abnormal assembly and accumulation of neurofilaments in the cell body and proximal axons of motor neurons is a characteristic feature of the pathology of ALS [31]. However, it is not yet known whether the abnormal accumulation of neurofilaments occurs as a consequence of axonal transport blockade or whether the accumulation of these proteins leads to secondary impairment of axonal transport. There is conflicting evidence that there may be an excess of phosphorylated neurofilament in the cell bodies of motor neurons in ALS. Some studies have reported an increase in the perikaryal expression of phosphorylated neurofilaments $[47,54,81]$ but others have failed to replicate this observation [44]. Ubiquitinated inclusions with compact or Lewy body-like morphology in residual motor neurons in ALS cases may show immunoreactivity for neurofilament epitopes $[38,56]$. Some cases of SOD1-related familial ALS show dramatic hyaline conglomerate inclusions, which show immunoreactivity indicating the presence of phosphorylated and non-phosphorylated neurofilaments, within the perikarya and axons of motor neurons [38, 72] (Fig. 1).

Mutations of the NF-H gene have been found in association with a small number of cases of sporadic ALS [28, 87] highlighting the importance of neurofilaments in the normal health of motor neurons.

Transgenic mice which overexpress NF-L or NF-H subunits develop motor neuron pathology $[21,94]$ as do mice expressing mutations in the NF-L subunit [43]. Accumulations of abnormal neurofilaments are also known to be present in some of the mutant SOD1 transgenic mice 


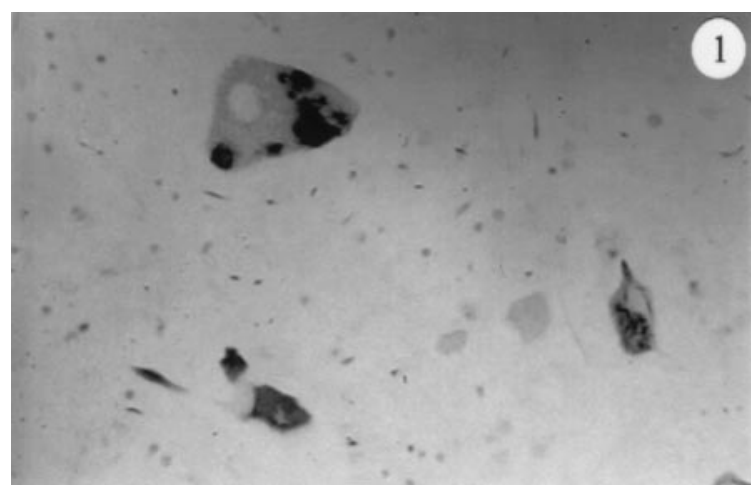

Fig. 1 Residual motor neurons in a case of familial ALS with an I113T SOD1 mutation. Hyaline conglomerate inclusions are seen within the motor neuron cell bodies and axons, which show immunoreactivity for phosphorylated and non-phosphorylated neurofilaments

[89]. These in vivo models demonstrate that disruption of neurofilament assembly can selectively injure motor neurons.

Morrison and colleagues showed that the presence of nonphosphorylated neurofilament in spinal cord neurons correlates with vulnerability to injury and cell death in the presence of SOD1 mutations [51].

In neuronal cell culture models of oxidative stress, neurofilament proteins appear to show differential vulnerability to free radical damage [20]. Motor neuron cell lines transfected with mutant SOD1 also show accumulations of neurofilament proteins which are not seen in the presence of normal SOD1. One of the major hypotheses for the toxic gain of function associated with SOD1 mutations is that altered affinity of the active site of the mutant enzyme for peroxynitrite may lead to nitration of tyrosine residues of susceptible proteins, as a result of generation of nitronium residues [7]. It has been shown that the tyrosine residues in the rod and tail domains of the neurofilament light subunit are more susceptible to SOD1-catalysed nitration compared to other proteins in the CNS [22]. Other features which may contribute to the vulnerability of neurofilament proteins to oxidative stress include their long half-lives and their high content of lysine, an amino acid residue susceptible to oxidative modification.

\section{Cell specific profile of glutamate receptors expressed by motor neurons}

There is a body of circumstantial evidence, reviewed in several recent publications $[45,69,75]$ implicating glutamatergic toxicity as a contributory factor in the pathogenesis of motor neuron injury in ALS. Cultured mammalian motor neurons are susceptible to toxic effects via activation of either NMDA or non-NMDA glutamate receptors [27]. Intrathecal injection of kainic acid in mice preferen- tially injures anterior horn cells and induces the formation of abnormally phosphorylated neurofilaments, a cytoskeletal abnormality found in ALS [34]. In spinal cord explants, chronic pharmacological blockade of glutamate transporter function results in degeneration of motor neurons with a time course of weeks [70].

Upper motor neurons in direct contact with lower motor neurons are thought to be glutamatergic, as are local excitatory interneurons in the spinal cord. Consequently, human motor neurons have a high density of glutamate receptors [76]. However, given the widespread distribution of the glutamate neurotransmitter system in the human CNS, some explanation is required to account for why motor neurons may be selectively vulnerable to glutamate toxicity.

Postsynaptic glutamate receptors are divided into two major classes, ionotropic which are ligand-gated ion channels and metabotropic which are coupled through G proteins to intracellular second messenger systems [91]. The ionotropic receptors are subclassified into three major groups according to the pharmacological specificity of their selective agonists: N-methyl-D-aspartate (NMDA) receptors; AMPA ( $\alpha$-amino-3-hydroxy-5-methyl-4-isoxazole propionic acid) receptors; and kainate receptors. Molecular studies indicate the presence of fourteen different genes encoding ionotropic glutamate receptor subunits [32]. The properties of postsynaptic glutamate receptors are defined by the specific combination of receptor subunits present in the receptor complex [82]. Further molecular and functional diversity arises from alternative splicing of genes encoding receptor subunits and from posttranscriptional RNA editing [13, 35]. Therefore, the mechanisms exist for particular classes of neurons, such as motor neurons, to express a unique molecular profile of ionotropic glutamate receptors, suited to cell-specific functional properties.

Normal glutamate neurotransmission involves the vesicular release of glutamate into the synaptic cleft where it activates postsynaptic receptors. Active re-uptake of glutamate from the synaptic cleft is carried out by several transporter proteins located on both glial and neuronal cells. This process terminates the excitatory transmitter signal. If, however, there is some disturbance to the normal excitatory transmission process, glutamate can induce excitotoxic neuronal damage [60]. Over-stimulation of glutamate receptors results in excessive influx of calcium leading to initiation of a cascade of harmful biochemical processes within the cell.

It has become apparent, following the original work of Novelli and co-workers [59], that excitotoxic cellular injury can occur as a secondary process, triggered by any primary pathological event which results in compromise of neuronal energy status. Impairment of neuronal glucose metabolism, reduction of ATP production or dysfunction of $\mathrm{Na}+\mathrm{K}+-\mathrm{ATPa} e s$ will result in loss of the ability of the neuron to maintain a normal resting membrane potential. 
In this circumstance, the voltage-dependent $\mathrm{Mg}^{++}$block of the NMDA receptor channel may be removed, resulting in over-activation of NMDA receptors by normal levels of neurotransmitter glutamate [6].

The concept of secondary excitotoxicity is attractive as a contributory mechanism to neuronal cell death in chronic neurodegenerative diseases such as ALS. In this situation, activation of glutamate receptors could prove toxic without any underlying abnormality in the expression or modulation of glutamate or its receptors. It could also account for the anatomical specificity seen in neurodegenerative diseases. A variety of primary disturbances in neuronal metabolism could result in predisposition to secondary toxic effects of glutamate.

Human motor neurons have a high level of expression of the universal NMDA receptor subunit, NMDAR1. To date there is little information on the expression of the eight splice variants of NMDAR1, and that of NMDAR2A-2D subunits by motor human neurons. This information will be of interest because specific molecular features of NMDA receptor assembly may have important effects on cellular vulnerability to glutamate toxicity [88]. Autoradiographic studies have shown an increased density of binding sites for NMDA and non-NMDA receptor ligands in ALS, particularly in the intermediate grey matter of the spinal cord and deep layers of the motor cortex $[74,77]$.

The AMPA subtype of glutamate receptor is responsible for much of the fast excitatory transmission in the mammalian CNS. AMPA receptors are composed of four protein subunits, GluR1-GluR4. The GluR2 subunit is of particular functional significance because its presence renders the AMPA receptor impermeable to calcium. Most AMPA receptors in the human CNS include the edited form of the GluR2 subunit and are calcium impermeable $[9,24]$. This is physiologically important since calcium entry via glutamate receptor ion channels is one of the key processes for triggering second messenger and toxic events [49].

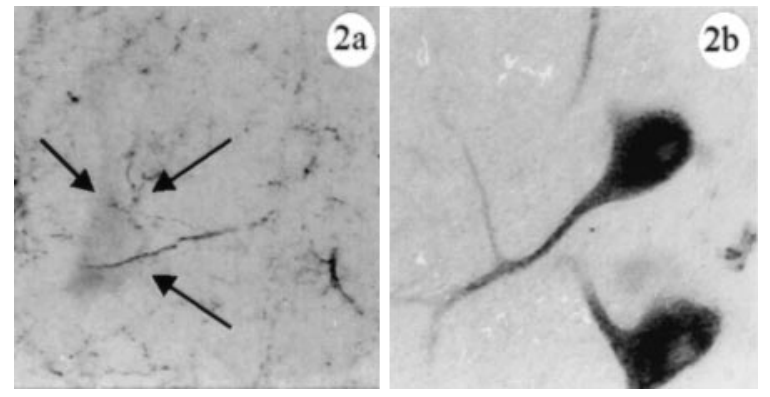

Fig. 2 Immunohistochemistry using an antibody which specifically detects the GluR2 AMPA receptor subunit. Upper motor neurons (Betz cells) show absent staining (a), in contrast to the strong staining shown by many other neuronal groups, e.g. the cerebellar Purkinje cells (b)
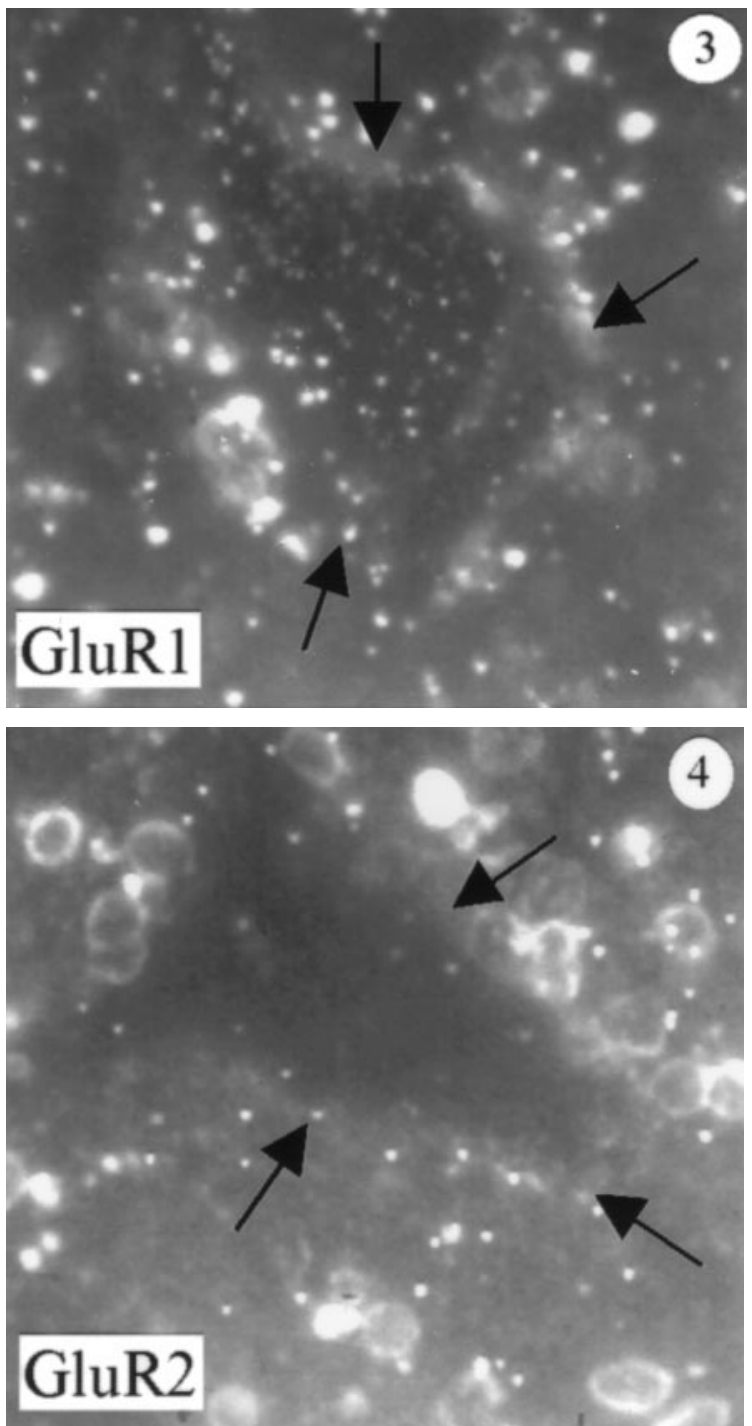

Fig. 3 and 4 In situ hybridisation using riboprobes for the GluR1 and GluR2 AMPA receptor subunits. Spinal motor neurons show a relatively strong expression of GluR1 mRNA (Fig. 3), but there is no discernible hybridisation signal above the background level for GluR2 mRNA (Fig.4). Motor neuron perikarya are indicated by arrows

The level of GluR2 expression by mammalian motor neurons has been controversial [40, 84-86, 92]. An in situ hybridisation study has clearly shown that upper and lower motor neurons in the human CNS have low expression of mRNA for the GluR2 AMPA receptor subunit [92] (Figs. 3 and 4). The low expression of the GluR2 protein subunit in human motor neuron cell groups has also been demonstrated using a GluR2 specific antibody [78] (Fig. 2). This low expression of GluR2 by human motor neurons implies that most of the surface AMPA receptors expressed by this cell group are likely to be atypical and calcium permeable. This feature suggests that human motor 
neurons may differ from many other groups of neurons in the human CNS in expressing a high proportion of calcium permeable AMPA receptors.

However, in a recent study, the distribution of GluR2 immunoreactivity was investigated in the CNS of control and SOD1 transgenic mice. GluR2 was present in the synapses of neurons in the dorsal spinal cord as well as motor neurons, and the percentage of labelled synapses and numbers of GluR2 positive immunogold particles per synapse did not significantly vary between these neuronal groups [53]. It is possible that species differences account for some of the discrepancies reported between the expression of glutamate receptors by murine and human motor neurons.

The physiological significance of atypical calcium permeable AMPA receptors remains to be fully elucidated, though there is evidence that they may have a role in strengthening synaptic transmission in specific neurons, in activating $\mathrm{Ca}^{++}$-dependent $\mathrm{K}^{+}$channels and in the inactivation of NMDA receptors [65]. With regard to the pathological implications of the expression of calcium permeable AMPA receptors lacking the GluR2 subunit, it has been shown that this molecular profile of AMPA receptors confers selective vulnerability to glutamate toxicity in vitro and vivo $[15,18]$.

Roy et al. have demonstrated, using a rat primary motor neuron cell culture model, microinjected to express SOD1 mutations, that normally non-toxic glutamatergic input, particularly via calcium-permeable AMPA/kainate receptors, is a major factor in the vulnerability of motor neurons to the toxicity of SOD1 mutations [73]. In the embryonic primary motor neurons used in this study, GluR2 was detected at a population of motor neuron dendritic synapses, but with a more restricted distribution compared to GluR4.

\section{Glutamate transporters}

The glial glutamate transporter GLT-1 or its human equivalent EAAT-2 is of particular interest in ALS. Motor neurons which are vulnerable to pathology in ALS appear to have a much greater perisomatic expression of the EAAT2 protein compared to motor neuron groups such as the oculomotor neurons which are normally spared in the disease [50] (Figs. 5 and 6). If the level of expression or functional capacity of this transporter protein is reduced, one could postulate that the consequences would be more devastating for cells that are normally heavily reliant on its presence.

It is of interest that the EAAT2 protein is known to be particularly vulnerable to damage by oxidative stress [90]. It is also noteworthy that reduced expression of the GLT-1 protein (the murine equivalent of EAAT2) [12] and decreased function of the high affinity $\mathrm{Na}^{+}$-dependent transport of glutamate in synaptosomal preparations [14] have
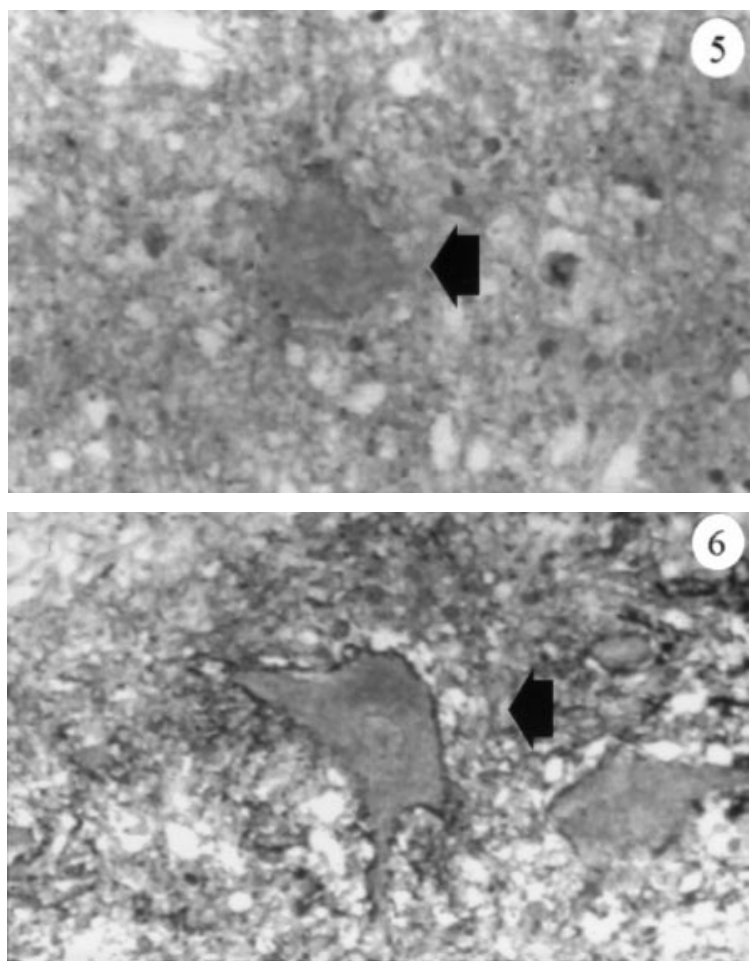

Fig. 5 and 6 Expression of the glutamate transporter protein EAAT2 in the vicinity of human motor neurons detected by immunohistochemistry. There is much greater perisomatic expression of EAAT2 in relation to spinal motor neurons (Fig. 6) in comparison with oculomotor neurons (Fig.5). Cell bodies of motor neurons indicated by arrows

been reported in transgenic mice with ALS-related SOD1 mutations.

There is variation in the results of studies investigating the expression of glutamate transporter proteins within the CNS in the ALS disease state. Immunoblotting studies performed on tissue homogenates, using anti-peptide polyclonal antibodies to glutamate transporter proteins, showed a substantial loss of expression of the glial transporter EAAT2 in the motor cortex and spinal cord of ALS cases [71]. However, examination of EAAT2 in situ, using immunohistochemistry employing a monoclonal antibody to recombinant human EAAT2, has demonstrated no reduction in the expression of EAAT2 in the motor cortex, although a significant decrease in EAAT2 immunoreactivity was observed throughout the grey matter regions of the lumbar spinal cord in ALS patients compared to controls [29]. Though the detailed results differ, both of these studies provide evidence for alteration of glutamate transporter expression in ALS.

No evidence exists to suggest that genomic mutations in EAAT2 commonly underlie either familial or sporadic ALS [4]. Northern blotting experiments show no alteration in the overall amount of EAAT2 mRNA in ALS [10]. Recently, abnormal mRNA transcripts have been re- 
ported including exon-skipping and intron-retention splice variants [46]. These abnormal transcripts were not present in controls but were found in $65 \%$ of ALS cases and were confined to pathologically affected areas of CNS tissue, as well as being detectable in CSF. The authors proposed that these variant mRNAs might result from gene specific RNA processing errors, confined to particular anatomical sites in the CNS. As yet there is no clear explanation as to why the aberrant RNA processing should only affect EAAT2 pre-mRNA and why only in the motor cortex and spinal cord. However, another study has suggested that alternatively spliced forms of EAAT2 mRNA may not be specific to ALS and could also be detected in control cases [57]. Further investigation is therefore required to clarify the role of alteration in the expression and function of glutamate transporter proteins in the pathogenesis of ALS.

\section{Calcium binding proteins and motor neurons}

Calcium is fundamental to many normal cellular processes including neurotransmission and the regulation of intracellular second messenger systems. Under normal circumstances, the intracellular $\mathrm{Ca}^{++}$concentration is tightly controlled at a level below $0.1 \mu \mathrm{M}$. Regulation is maintained by a complex system of compartmentalisation and transportation involving binding to calcium buffering proteins, including parvalbumin and calbindin D28k [5], sequestration within organelles such as the endoplasmic reticulum and mitochondria [63], and transfer to the extracellular environment via ion exchangers. Following influx into the cytosol, calcium binds to calmodulin and stimulates the activity of a variety of enzymes including calcium-calmodulin kinases and calcium sensitive adenylate cyclases. These enzymes transduce the calcium signal and effect short-term biological responses such as the modification of synaptic proteins and long lasting neuronal responses that require changes in gene expression.

Intracellular calcium homeostasis is linked with other potential mechanisms underlying degeneration of motor neurons such as glutamate toxicity, oxidative stress and mitochondrial dysfunction. Sustained elevation of intracellular calcium can result in activation of a cascade of damaging biochemical events. These calcium-activated biochemical processes can injure the neuron both directly and through the generation of free radicals [49]. Up to a certain point, these changes are reversible, as demonstrated by the neuroprotective effects of glutamate receptor antagonists applied several hours after an excitotoxic insult. The molecular factors determining that a neuron is committed to die have not been established with certainty, but are likely to include induction of cell-death genes and the severity of cytoskeletal disorganisation.

A further molecular feature of motor neuron groups vulnerable to the pathological process in ALS may render
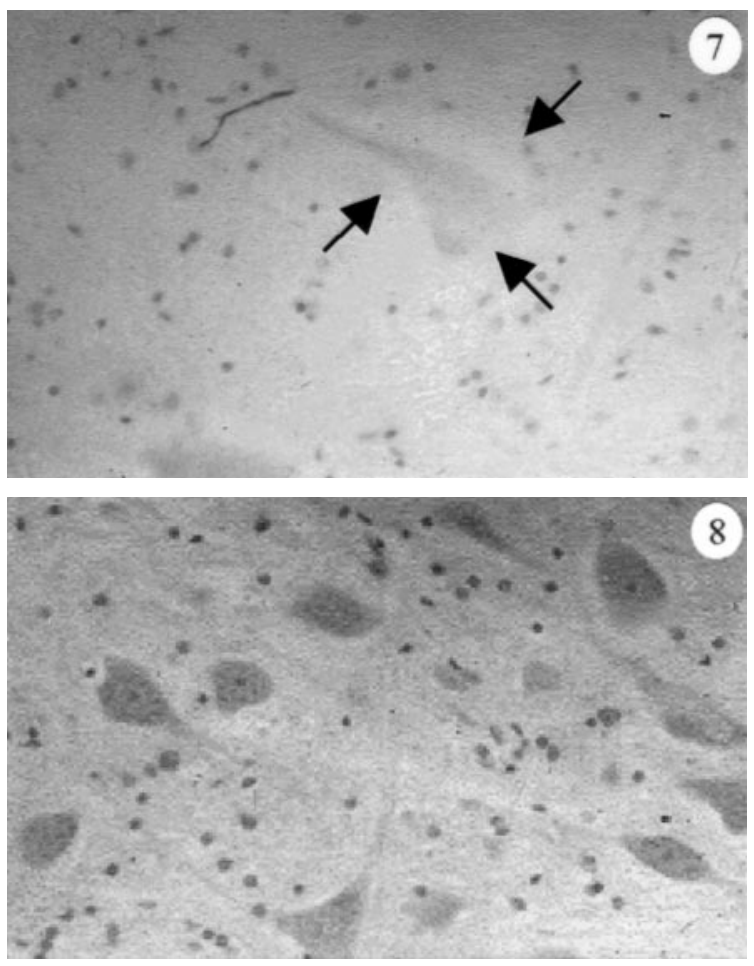

Fig. 7 and 8 The calcium binding protein parvalbumin is not expressed by human spinal motor neurons (Fig. 7), but is expressed within the cell bodies of oculomotor neurons (Fig. 8), as detected by immunohistochemistry. In Fig. 7 the cell body of a lumbar motor neuron is indicated by arrows

these cell groups unusually susceptible to glutamatergic toxicity. Human motor neurons that are vulnerable in ALS do not express the calcium binding proteins calbindin D28k and parvalbumin. Less vulnerable motor neuron groups such as the oculomotor nucleus and Onuf's nucleus express parvalbumin and calbindin respectively $[2$, 37] (Figs. 7 and 8). These proteins buffer intracellular calcium and play an important role in protecting neurons from calcium-mediated injury following activation of glutamate receptors. A direct relationship has been shown between cellular calcium buffering capacity and resistance to toxicity [48]. Thus, the combination of the low expression of the GluR2 AMPA receptor subunit and the absence of calcium buffering proteins may result in ALSsusceptible motor neurons being particularly vulnerable to calcium mediated toxic events following glutamate receptor activation.

A recent study demonstrated that motor neurons of transgenic mice with a G93A SOD1 mutation exhibit alterations in intracellular calcium [80]. The cell bodies and proximal dendrites of spinal motor neurons contained small calcium filled vacuoles in mice aged 60 days. Oculomotor neurons, however, showed only minimal evidence of degeneration, with no vacuolation and no increased calcium or alteration in intracellular calcium dis- 
tribution. The conclusions drawn from this work were that free radical-mediated stress induced by mutant SOD1 appeared to induce deleterious changes in intracellular calcium distribution in motor neuron populations lacking calbindin D28K and/or parvalbumin while motor neurons possessing these calcium-binding proteins were more resistant to the oxidative stress. In addition, Morrison et al. showed that the presence of calbindin appears to confer resistance to vulnerability fo neurons in the spinal cord of SOD1 transgenic mice [52].

\section{$\mathrm{Cu} / \mathrm{Zn}$ superoxide dismutase (SOD1) mutations and motor neurons}

Mutations in the SOD1 gene account for about $20 \%$ of familial cases of ALS [68] and 2\% of cases of ALS as a whole. The SOD1 protein is widely expressed in the mammalian CNS and indeed accounts for about one percent of all brain protein. The ubiquitous expression of this free radical scavenging enzyme, which forms a major component of the defence system protecting intracellular components from free radical induced injury, is difficult to reconcile with the selective damage to motor neuron cell groups in the presence of SOD1 mutations. Motor neurons normally have a very high content of SOD1 protein compared to other cells in the nervous system. Immunohistochemical localisation of SOD1 protein in motor neurons reveals the presence of SOD1 in the cell body and in the axonal processes extending to the neuromuscular junction $[64,79]$ (Figs. 9 and 10). It is plausible that this reflects the importance to motor neurons of a robust defence against oxidative stress. This requirement may, however, render motor neurons more vulnerable to injury in the presence of mutant SOD1 proteins. It is of interest that microinjection of SOD1 expression constructs into primary neurons in culture enhances the naturally occurring cell death of motor neurons, but not of other neuronal types [26].

It is not yet established whether a loss of function or a toxic gain of function of mutant SOD1, or both, is responsible for motor neuron injury. There is, however, compelling evidence favouring the gain of function hypothesis. Many of the missense mutations in SOD1 have the potential to alter the active site of the SOD1 enzyme. $\mathrm{X}$-ray crystallographic studies have demonstrated that the active channel of the mutant SOD1 protein is larger than that of the wild-type enzyme, enabling greater accessibility or unshielding of the copper active site [25]. Such changes could allow mutant SOD1 to react with additional substrates such as hydrogen peroxide and peroxynitrite, as well as its normal substrate of superoxide anions $[7,11]$. These aberrant reactions could result in increased cellular production of highly reactive and damaging free radical species such as hydroxyl radicals and nitronium ions. Neurofilament proteins and neurotrophic factor receptors are proteins particularly susceptible to damage in

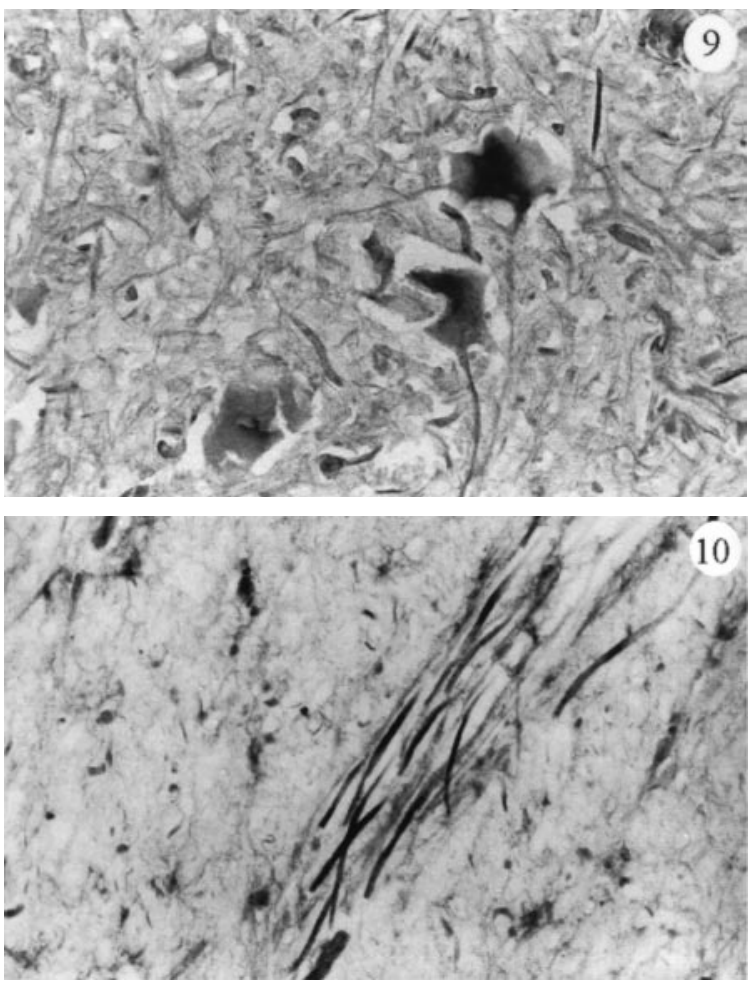

Fig. 9 and 10 Lumbar spinal motor neuron cell bodies (Fig. 9) and axonal processes (Fig. 10) show strong immunostaining for the $\mathrm{Cu} / \mathrm{Zn}$ superoxide dismutase (SOD1) protein in comparison with other groups of neurons in the human CNS

these circumstances and both are crucial for the normal function of motor neurons [7].

\section{Other neurochemical features of motor neurons}

Motor neurons have other specific neurochemical features which could potentially be relevant to selective vulnerability. Both thyrotropin releasing hormone (TRH) and serotonin $(5-\mathrm{HT})$ play a role in modulating the excitability of motor neurons $[8,61]$. The glycine inhibitory neurotransmitter system is particularly important in relation to motor neurons in the brainstem and spinal cord [95]. There is emerging evidence for the presence of $\operatorname{GABA}(\gamma$ amino butyric acid) as well as glycine receptors on lower motor neurons. Recent evidence suggests that GABA and glycine may be released from the same terminals in the vicinity of motor neurons [41] and this dual inhibitory influence may be a relatively specific feature for this cell group. Motor neurons appear to have the highest concentration in the nervous system of the dipeptide $\mathrm{N}$-acetyl-aspartyl glutamate which may act as a precursor of the neurotransmitter glutamate [3].

In relation to neurotrophic factors, a large number of trophic molecules from different gene families have been 
shown to promote the survival of motor neurons in vitro or in vivo. However, few of these polypeptides have specific effects only on motor neurons. Adult motor neurons express trkB receptors which mediate the effects of brain derived neurotrophic factor (BDNF) and neurotrophin $4 / 5$, and trkC receptors which mediate the effects of neurotrophin $3[39,62]$.

\section{Exposure of motor neurons outside the CNS}

A further unique feature of lower motor neurons, which could be potentially important in selective vulnerability, is their exposure outside the CNS at the neuromuscular junction. Thus motor neurons, lacking the protection of the blood-brain barrier at the axon termini, may be exposed to potentially deleterious systemic factors at this site. Motor neurons are intimately connected with muscle at the neuromuscular junction and their health may be uniquely dependent on retrograde transport of trophic factors and signalling molecules from muscle.

\section{Conclusion}

Current evidence indicates that cell death in ALS reflects a complex interplay between genetic factors, oxidative stress, toxic activation of glutamate receptors and damage to critical target proteins and organelles (Fig. 11). The relative importance of these factors may vary in different subgroups of patients. In relation to each of these putative pathophysiological factors, there are molecular features of human motor neurons which may make this cell group vulnerable to such insults. In the recent past we have seen

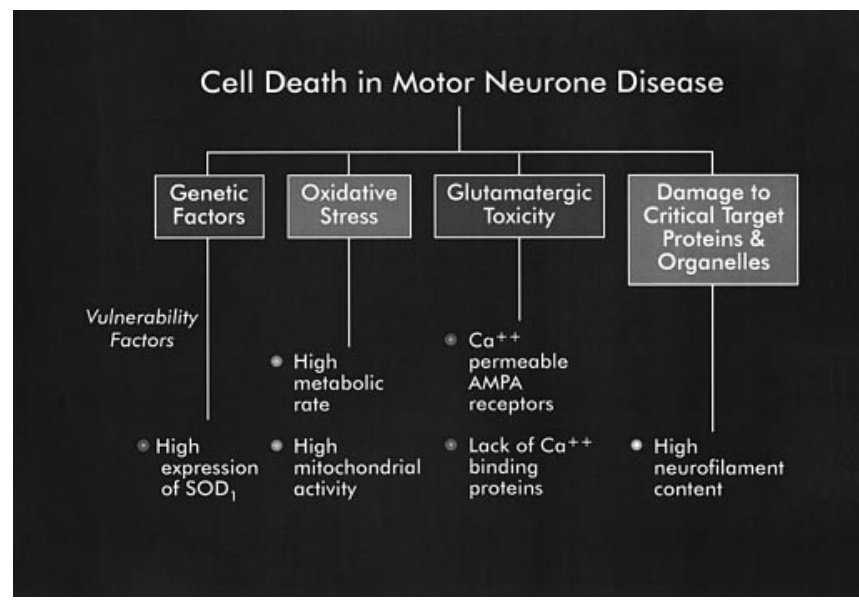

Fig. 11 Summary of factors which are likely to be playing a role in the cell death of motor neurons, together with specific phenotypic features of motor neurons which may render this cell group vulnerable to such insults

the development of good cellular and animal models of ALS. These models will be important in defining precise molecular targets which are preferentially injured during motor neuron degeneration and will also allow the development of neuroprotective therapies which take advantage of the cell specific molecular features of human motor neurons.

Acknowledgements PJS is supported by the Wellcome Trust as a Senior Fellow in Clinical Science. CJE is also supported by the Wellcome Trust. The Motor Neurone Disease Association also supports the work of the authors.

\section{References}

1. Abrahams S, Goldstein LH, Al-Chalabi A, Pickering A, Morris RG, Passingham RE, Brooks DJ, Leigh PN (1997) Relation between cognitive dysfunction and pseudobulbar palsy in amyotrophic lateral sclerosis. J Neurol Neurosurg Psychiatry 62:464-472

2. Alexianu ME, Ho BK, Mohammed AH, La Bella V, Smith RG, Appel S (1994) The role of calcium-binding proteins in selective motoneuron vulnerability in amyotrophic lateral sclerosis. Ann Neurol 36:846-858

3. Anderson KJ, Monaghan DT, Cangro CB, Namboodiri MAA, Neale JH, Cotman CW (1986) Localization of $\mathrm{N}$-acetylaspartylglutamate-like immunoreactivity in selected areas of the rat brain. Neurosci Lett 72:14-20
4. Aoki M, Lin CLG, Rothstein JD, Geller BA, Hosler BA, Munsat TL, Horvitz HR, Brown RH (1998) Mutations in the glutamate transporter EAAT2 gene do not cause abnormal EAAT2 transcripts in amyotrophic lateral sclerosis. Annals of Neurology 43 : 645-653

5. Baimbridge K, Celio MR, Rogers $\mathrm{SH}$ (1992) Calcium binding proteins in the nervous system. Trends Neurosci 15 : 303-308

6. Beal MF, Hyman BT, Koroshetz W (1993) Do defects in mitochondrial energy metabolism underlie the pathology of neurodegenerative diseases. Trends Neurol Sci 16:125-131

7. Beckman JS, Crow JP (1993) Pathological implications of nitric oxide, superoxide and peroxynitrite formation. Biochem Soc Trans 21:330-334
8. Bedard PJ, Tremblay LE, Barbeau H, Filion M, Maheux R, Richards CL, Dipaulo T (1987) Action of 5-hydroxytryptamine, substance $\mathrm{P}$, thyrotropinreleasing hormone and clonidine on motor neurone excitability. Can J Neurol Sci 14:506-509

9. Bettler B, Egebjerg J, Sharma G, Pecht G, Hermans-Borgmeyer I, Moll C, Stevens CF, Heinemann S (1992) Cloning of a putative glutamate receptor: a low-affinity kainate binding subunit. Neuron $8: 257-265$

10. Bristol LA, Rothstein JD (1996) Glutamate transporter gene expression in amyotrophic lateral sclerosis motor cortex. Ann Neurol 39: 676-679

11. Brown RH (1995) Amyotrophic lateral sclerosis: recent insights from genetics and transgenic mice. Cell 80:687-692 
12. Bruijn LI, Becher MW, Lee MK, Anderson KL, Jenkins NA, Copeland NG, Sisodia SS, Rothstein JD, Borchelt DR, Price DL, Cleveland DW (1997) ALSlinked SOD1 mutant G85R mediates damage to astrocytes and promotes rapidly progressive disease with SOD1 containing inclusions. Neuron 18:327338

13. Burnashev N, Monyer H, Seeburg PH, Sakmann B (1992) Divalent ion permeability of AMPA receptor channels is dominated by the edited form of a single subunit. Neuron 8:189-198

14. Canton T, Pratt J, Stutzmann JM, Imperato A, Boireau A (1998) Glutamate uptake is decreased tardively in the spinal cord of FALS mice. NeuroReport 9:775-778

15. Carriedo SG, Yin H-Z, Lamberta R, Weiss JH (1995) In vitro kainate injury to large SMI-32(+) spinal neurons is $\mathrm{Ca}^{++}$dependent. NeuroReport 6 : 945-948

16. Chari G, Shaw PJ, Sahgal A (1996) Non-verbal visual attention, but not recognition memory or learning processes are impaired in motor neurone disease. Neuropsychologica 34 : 377-385

17. Chiu AY, Zhai P, Dal Canto MC, Peters TM, Kwon YW, Prattis SM, Gurney ME (1995) Age-dependent penetrance of disease in a transgenic mouse model of familial amyotrophic lateral sclerosis. Mol Cell Neurosci 6:349362

18. Choi DW (1995) Calcium: still centerstage in hypoxic-ischemic neuronal death. Trends Neurol Sci 18:58-60

19. Comi GP, Bordoni A, Salani S, Franceschina L, Sciacco M, Prelle A, Fortunato F, Zeviani M, Napoli L, Bresolin N, Moggio M, Ausenda CD, Taanman JW, Scarlato G (1998) Cytochrome c oxidase subunit I microdeletion in a patient with motor neuron disease. Ann Neurol 43:110-116

20. Cookson MR, Thatcher NM, Ince PG, Shaw PJ (1996) Selective loss of neurofilament proteins after exposure of differentiated IMR-32 neuroblastoma cells to oxidative stress. Brain Res 738 : 162-166

21. Cote F, Collard JF, Julien JP (1993) Progressive neuropathy in transgenic mice expressing the human neurofilament heavy gene: a mouse model of amyotrophic lateral sclerosis. Cell 73: 35-46

22. Crow JP, Ye YZ, Strong M, Kirk M, Barnes S, Beckman JS (1997) Superoxide dismutase catalyzes nitration of tyrosines by peroxynitrite in the rod and head domains of neurofilament-L. J Neurochem 69: 1945-1953
23. Curti D, Malaspina A, Facchetti G, Camana C, Mazzini L, Tosca P, Zerb F, Ceroni M (1996) Amyotrophic lateral sclerosis: oxidative energy metabolism and calcium homeostasis in peripheral blood lymphocytes. Neurology 47 : 1060-1064

24. Day NC, Williams TL, Ince PG, Kamboj RK, Lodge D, Shaw PJ (1995) Distribution of AMPA-selective glutamate receptor subunits in the human hippocampus and cerebellum. Mol Brain Res 31:17-32

25. Deng H-X, Hentati A, Tainer JA, Iqbal Z, Cayabyab A, Hung W-Y, Getzoff ED, Hu P, Herzfeldt B, Roos RP, Warner C, Deng G, Soriano E, Smyth C, Parge HE, Ahmed A, Roses AD, Hallewell RA, Pericak-Vance MA, Siddique T (1993) Amyotrophic lateral sclerosis and structural defects in $\mathrm{Cu}$, Zn superoxide dimutase. Science 261: 1047-1051

26. Durham HD, Roy J, Dong L, Figlewicz DA (1997) Aggregation of mutant $\mathrm{Cu} / \mathrm{Zn}$ superoxide dismutase proteins in a culture model of ALS. J Neuropathol Exp Neurol 56:523-530

27. Estevez AG, Stutzmann J-M, Barbeito L (1995) Protective effect of riluzole on excitatory amino acid-mediated neurotoxicity in motoneuron-enriched cultures. Eur J Pharmacol 280:47-53

28. Figlewicz DA, Krizus A, Martinoli MG, Meininger V, Dib M, Rouleau GA, Julien JP (1994) Variants of the heavy neurofilament subunit are associated with the development of amyotrophic lateral sclerosis. Human Mol Genet 3:1757-1761

29. Fray AE, Banner SJ, Ince PG, Milton ID, Usher PA, Shaw PJ (1998) Expression of the glial glutamate transporter EAAT2 in motor neurone disease: an immunocytochemical study. Europ J Neurosci 10:2481-2489

30. Fujita K, Yamauchi M, Shibayama K, Ando M, Honda M, Nagata Y (1996) Decreased cytochrome c oxidase activity but unchanged superoxide dismutase and glutathione peroxidase activities in the spinal cord of patients with amyotrophic lateral sclerosis. J Neurosci Res $45: 276-281$

31. Hirano A (1991) Cytopathology of amyotrophic lateral sclerosis. Adv Neurol 56:91-101

32. Hollmann M, Heinemann S (1994) Cloned glutamate receptors. Annu Rev Neurosci 17:31-108

33. Hudson AJ (1981) Amyotrophic lateral sclerosis and its association with dementia, Parkinsonism and neurological disorders: a review. Brain 104: 217-247

34. Hugon J, Vallat JM (1990) Abnormal distribution of phosphorylated neurofilaments in neuronal degeneration induced by kainic acid. Neurosci Lett 119:45-48
35. Hume RI, Dingledine R, Heinemann S (1991) Identification of a site in glutamate receptor subunits that controls calcium permeability. Science 253: 1028-1031

36. Ince PG, Shaw PJ, Slade JY, Jones C, Hudgson P (1996) Familial amyotrophic lateral sclerosis with a mutation in exon 4 of the $\mathrm{Cu} / \mathrm{Zn}$ superoxide dismutase gene: pathological and immunocytochemical changes. Acta Neuropath $92: 395-403$

37. Ince PG, Stout N, Shaw PJ, Slade J, Hunziker W, Heizmann CW, Baimbridge KG (1993) Parvalbumin and calbindin D-28k in the human motor system and in motor neurone disease. Neuropath Appl Neurobiol 19:291299

38. Ince PG, Tomkins J, Slade JY, Thatcher NM, Shaw PJ (1998) Amyotrophic lateral sclerosis associated with genetic abnormalities in $\mathrm{Cu} / \mathrm{Zn}$ superoxide dismutase: molecular pathology of five new cases and comparison with previous reports and 73 cases of sporadic ALS. J Neuropathol Exp Neurol 57:895-904

39. Ip NY, Stitt TN, Tapley P, Klein R, Glass DJ, Fandl J, Greene LA, Barbacid M, Yancopoulos GD (1993) Similarities and differences in the way neurotrophins interact with Trk receptors in neuronal and nonneuronal cells. Neuron 10:137-149

40. Jakowec MW, Fox AJ, Martin LJ, Kalb RG (1995) Quantitative and qualitative changes in AMPA receptor expression during spinal cord development. Neuroscience 67(4) : 893-907

41. Jonas P, Bischofberger J, Sandkuhler J (1998) Corelease of two fast neurotransmitters at a central synapse. Science $281: 419-424$

42. Kong JM, Xu ZS (1998) Massive mitochondrial degeneration in motor neurons triggers the onset of amyotrophic lateral sclerosis in mice expressing a mutant SOD1. J Neurosci 18 : 3241-3250

43. Lee MK, Marszalek JR, Cleveland DW (1994) A mutant neurofilament subunit causes massive selective motor neuron death: implications for the pathogenesis of human motor neuron disease. Neuron 13:975-988

44. Leigh PN, Dodson A, Swash M, Brion J-P, Anderton BH (1989) Cytoskeletal abnormalities in motor neuron disease: an immunocytochemical study. Brain 112:521-535

45. Leigh PN, Meldrum BS (1996) Excitotoxicity in ALS. Neurology 47:S221S227 
46. Lin CLG, Bristol LA, Dykes-Hoberg M, Crawford T, Clawson L, Rothstein JD (1998) Aberrant RNA processing in a neurodegenerative disease: the cause for absent EAAT2, a glutamate transporter in amyotrophic lateral sclerosis. Neuron 20:589-602

47. Manetto V, Sternberger NH, Perry G, Sternberger LA, Gambetti P (1988) Phosphorylation of neurofilaments in altered in amyotrophic lateral sclerosis. J Neuropathol Exp Neurol 47 : 642-653

48. Mattson MP, Guthrie PB, Kater SB (1989) A role of $\mathrm{Na}^{+}$-dependent $\mathrm{Ca}^{2+}$ extrusion in protecting against neuronal excitotoxicity. FASEB J 3 : 2519-2526

49. Meldrum B, Garthwaite J (1990) Excitatory amino acid neurotoxicity and neurodegenerative disease. Trends Pharmacol Sci 11:379-387

50. Milton ID, Banner SJ, Ince PG, Piggot NH, Fray AE, Thatcher N, Horne CHW, Shaw PJ (1997) Expression of the glial glutamate transporter EAAT2 in the human CNS: an immunocytochemical study. Mol Brain Res 52:1731

51. Morrison BM, Gordon JW, Ripps ME, Morrison JH (1996) Quantitative immunocytochemical analysis of the spinal cord of G86R superoxide dismutase transgenic mice: neurochemical correlates of selective vulnerability. J Comp Neurol 373:619-631

52. Morrison BM, Hof PR, Morrison JH (1998) Determinants of neuronal vulnerability in neurodegenerative diseases. Ann Neurol 44 (Suppl 1): S32S44

53. Morrison BM, Janssen WGM, Gordon JW, Morrison JH (1998) Light and electron microscopic distribution of the AMPA receptor subunit, GluR2, in the spinal cord of control and G86R mutant superoxide dismutase transgenic mice. J Comp Neurol 395 : 523-534

54. Munoz DG, Green C, Perl D, Selkoe DJ (1988) Accumulation of phosphorylated neurofilaments in anterior horn motorneurons of ALS patients. J Neuropathol Exp Neurol 47:9-18

55. Murakami N, Yoshida M (1995) Reappraisal of amyotrophic lateral sclerosis with dementia. Clin Neurol $35: 1560$ 1562

56. Murayama S, Ookawa Y, Mori H, Nakano I, Ihara Y, Kuzuhara S, Tomonaga M (1989) Immunocytochemical and ultrastructural study of Lewy-body-like inclusions in familial amyotrophic lateral sclerosis. Acta Neuropath 78:143-152

57. Nagai M, Abe K, Okamoto K, Itoyama Y (1998) Identification of alternative splicing forms of GLT-1 mRNA in the spinal cord of amyotrophic lateral sclerosis. Neurosci Lett 244:165-168
58. Nixon RA, Shea TB (1992) Dynamics of neuronal intermediate filaments: a developmental perspective. Cell Motil Cytoskeleton 22:81-91

59. Novelli A, Reilly JA, Lysko PG, Henneberry RC (1988) Glutamate becomes neurotoxic via the N-methyl-D-aspartate receptor when intracellular energy levels are reduced. Brain Research 451: 205-212

60. Olney JW, Adamo NJ, Ratner A (1971) Monosodium glutamate effects. Science 172:294

61. Ono H, Fukuda H (1982) Ventral root depolarization and spinal reflex augmentation by a TRH analog in rat spinal cord. Neuropharmacology 21 : 39-44

62. Oppenheim RW (1996) Neurotrophic survival molecules for motorneurons: an embarrasment of riches. Neuron 17 : 195-197

63. Orrenius S, McConkey DJ, Bellomo G, Nicotera P (1989) Role of Ca2+ in toxic cell killing. Trends Pharmacol Sci 10:281-284

64. Pardo CA, Xu Z, Borchelt DR, Price DL, Sisodia SS, Cleveland DW (1995) Superoxide dismutase is an abundant component in cell bodies, dendrites and axons of motor neurons and in a subset of other neurons. Proc Natl Acad Sci 92(4): 954-958

65. Pellegrini-Giampetro DE, Gorter JA, Bennett MVL, Zukin RS (1997) The GluR2 (GluR-B) hypothesis: $\mathrm{Ca}^{2+}$-permeable AMPA receptors in neurological disorders. TINS 20:464-470

66. Rakowicz WP, Hodges JR (1998) Dementia and aphasia in motor neuron disease: an underrecognised association? J Neurol Neurosurg Psychiatry $65: 881-889$

67. Richter C, Park JW, Ames BN (1988) Normal oxidative damage to mitochondrial and nuclear DNA is extensive. Proc Natl Acad Sci USA 85:64656467

68. Rosen DR, Siddique T, Patterson D, Figelwicz DA, Sapp P, Hantati A, Donaldson D, Goto J, O'Regan JP, Deng H-X, Rahmani Z, Krizus A, McKenna-Yasek D, Cayabyab A, Gaston SM, Berger R, Tanzi RE, Halperin JJ, Herzfeldt B, Bergh RVd, Hung WY, Bird T, Deng G, Mulder DW, Smyth C, Laing NG, Soriano E, Pericak-Vance MA, Haines J, Rouleau GA, Gusella JS, Horvitz HR, Brown RH (1993) Mutations in $\mathrm{Cu} / \mathrm{Zn}$ superoxide dismutase gene are associated with familial amyotrophic lateral sclerosis. Nature 362:59-62

69. Rothstein JD (1995) Excitotoxic mechanisms in the pathogensis of amyotrophic lateral sclerosis. Adv Neurol 68: 7-20
70. Rothstein JD, Jin L, Dykes-Hoberg M, Kuncl RW (1993) Chronic inhibition of glutamate uptake produces a model of slow neurotoxicity. Proc Natl Acad Sci USA 90:6591-6595

71. Rothstein JD, Van Kammen M, Levey AI, Martin LJ, Kuncl RW (1995) Selective loss of glial glutamate transporter GLT-1 in amyotrophic lateral sclerosis. Ann Neurol 38:73-84

72. Rouleau GA, Clark AW, Rooke K, Pramatarova A, Krizus A, Suchowersky O, Julien JP, Figlewicz D (1996) SOD1 mutation is associated with accumulation of neurofilaments in amyotrophic lateral sclerosis. Ann Neurol 39: 128-131

73. Roy J, Minotti S, Dong L, Figlewicz DA, Durham HD (1998) Glutamate potentiates the toxicity of mutant $\mathrm{Cu} / \mathrm{Zn}$ superoxide dismutase in motor neurons by post-synaptic calcium-dependent mechanisms. J Neurosci 18:96239684

74. Shaw PJ, Chinnery RM, Ince PG (1994) Non-NMDA receptors in motor neuron disease (MND): a quantitative autoradiographic study in spinal cord and motor cortex using [3H]CNQX and $[3 \mathrm{H}]$ kainate. Brain Res $655: 186-$ 194

75. Shaw PJ, Ince PG (1997) Glutamate, excitotoxicity and amyotrophic lateral sclerosis. J Neurol 244 (Suppl 2) : S3S14

76. Shaw PJ, Ince PG, Johnson M, Perry EK, Candy JM (1991) The quantitative autoradiographic distribution of [3H]MK-801 binding sites in the normal human brainstem in relation to motor neuron disease. Brain Res 572 : 276-280

77. Shaw PJ, Ince PG, Matthews JNS, Johnson M, Candy JM (1994) Nmethyl-D-aspartate (NMDA) receptors in the spinal cord and motor cortex in motor neurone disease: a quantitative autoradiographic study using [3H]MK801. Brain Res 637:297-302

78. Shaw PJ, Slade JY, Williams TL, Eggett CJ, Ince PG (1999) Low expression of GluR2 AMPA receptor subunit by human motor neurones. NeuroReport 10:261-265

79. Shaw PJ, Chinnery RM, Thagesen H, Borthwick G, Ince PG (1997) Immunocytochemical study of the distribution of the free radical scavenging enzymes $\mathrm{Cu} / \mathrm{Zn}$ superoxide dismutase (SOD1), Mn superoxide dismutase (MnSOD) and catalase in the normal human spinal cord and in motor neurone disease. J Neurol Sci 147: 115-125

80. Siklos L, Englehardt JI, Alexianu ME, Gurney ME, Siddique T, Appel SH (1998) Intracellular calcium parallels motoneuron degeneration in SOD-1 mutant mice. J Neuropath Exp Neurol $57: 571-587$ 
81. Sobue G, Hashizume Y, Yasuda T (1990) Phosphorylated high molecular weight neurofilament protein in lower motor neurons in ALS and other neurodegenerative diseases involving ventral horn cells. Acta Neuropathol 79: 402-408

82. Sommer B, Seeburg PH (1992) Glutamate receptor channels: novel properties and new clones. Trends Pharmacol Sci 13:291-296

83. Swash M, Scholz C, Vowks G, Ingram D (1988) Selective and asymmetrical vulnerability of corticospinal and spinocerebellar tracts in motor neurone disease. J Neurol Neurosurg Psychiatry 51 : 785-789

84. Temkin R, Lowe D, Jensen P, Hatt H, Smith DO (1997) Expression of glutamate receptor subunits in motoneurons. Mol Brain Res 52:38-45

85. Tolle TR, Berthele A, Zieglgansberger W, Seeburg PH, Wisden W (1993) The differential expression of 16 NMDA and non-NMDA receptor subunits in the rat spinal cord and in periaqueductal gray. J Neurosci 13:5009-5028
86. Tomiyama M, Rodriquez-Puertas R, Cortes R, Christnacher A, Sommer B, Pazos A, Palacios JM, Mengod G (1996) Differential regional distribution of AMPA receptor subunit messenger RNAs in the human spinal cord as visualised by in situ hybridization. Neuroscience 75:901-915

87. Tomkins J, Usher PA, Slade JY, Ince PG, Curtis A, Bushby K, Shaw PJ (1998) Novel insertion in the KSP region of the neurofilament heavy gene in amyotrophic lateral sclerosis. NeuroReport 9:3967-3970

88. Traynelis SF, Hartley M, Heinemann SF (1995) Control of proton sensitivity of the NMDA receptor by RNA splicing and polyamines. Science 268:873876

89. Tu PH, Raju P, Robinson KA, Gurney ME, Trojanowski JQ, Lee VM (1996) Transgenic mice carrying a human mutant superoxide dismutase transgene develop neuronal cytoskeletal pathology resembling human amyotrophic lateral sclerosis lesions. Proc Natl Acad Sci USA 93:3155-3160

90. Volterra A, Trott D, Cassutti P, Tromba C, Salvaggio A, Melcangi RC, Racagni G (1992) High sensitivity of glutamate uptake to extracellular free arachidonic acid levels in rat cortical synaptosomes and astrocytes. J Neurochem 59:600-606
91. Westbrook GL (1994) Glutamate receptor update. Curr Opin Neurobiol 4: 337-346

92. Williams TL, Day NC, Ince PG, Kamboj RK, Shaw PJ (1997) Calcium-permeable alpha-amino-3-hydroxy-5methyl-4-isoxazole propionic acid receptors: a molecular determinant of selective vulnerability in amyotrophic lateral sclerosis. Ann Neurol 42:200 207

93. Wong PC, Pardo CA, Borchelt DR, Lee MK, Copeland NG, Jenkins NA, Sisodia SS, Cleveland DW, Price DL (1995) An adverse property of a familial ALS-linked SOD1 mutation causes motor neuron disease characterized by vacuolar degeneration of mitochondria. Neuron 14(6): 1105-1116

94. Xu Z, Cork L, Griffin J, Cleveland D (1993) Increased expression of neurofilament subunit NF-L produces morphological alterations that resemble the pathology of human motor neuron disease. Cell $73: 23-33$

95.Zarbin MA, Wamsley JK, Kuhar MJ (1981) Glycine receptor: a light microscopic autoradiographic localization with $(3 \mathrm{H})$ strychnine. J Neurosci 1 : 532-547 